\title{
Generalized edema with hypoproteinemia as initial presentation of celiac disease in a 3-year-old boy: case report
}

\author{
Ivona Butorac Ahel, Mirna Šubat Dežulović, Goran Palčevski*
}

Edema is defined as abnormal accumulation of fluid in the interstitium. Differential diagnosis of generalized edema is very broad. Most often, renal and cardiac causes lead to generalized edema. The potential gastrointestinal causes of edema are liver failure and protein losing enteropathy including celiac disease and protein malnutrition. Generalized edema is rarely an initial manifestation of celiac disease. Hereby, we present a case of a 3-year-old boy with celiac disease, initially presented with generalized edema and hypoproteinemia.

Keywords: celiac disease; edema; hypoalbuminemia; child

\section{INTRODUCTION}

Edema is defined as a clinical condition characterized by abnormal fluid accumulation in the interstitium, resulting in generalized or peripheral tissue swelling. There are several mechanisms of edema formation, i.e. altered capillary hemodynamic, impaired lymphatic transport, and renal salt and water retention. Altered capillary hemodynamic results in shifting of fluid from the vascular space into the interstitium due to increased capillary hydrostatic pressure, decreased capillary oncotic pressure, or increased capillary permeability. Impaired lymphatic transport may be a consequence of abnormal development, dysfunction or obstruction of the lymphatic system. Renal retention of sodium and water may be primary or secondary and results in hypervolemia and increased vascular hydrostatic pressure (1). Differential diagnosis of generalized edema is very broad. The most common causes of edema in children, based on the pathogenesis, are shown in Table 1.

Celiac disease (CD) is a chronic immune-mediated disease of the small intestine that occurs in genetically susceptible individuals and is characterized by an aberrant response to gluten. Originally considered as a malabsorption syndrome of childhood, CD is nowadays recognized as a disease that can be diagnosed at any age and presents itself through various symptoms (2-5).

\section{CASE REPORT}

A 3-year-old boy was admitted to the hospital because of generalized edema that had first appeared on his eyelids and legs with an increase in body mass over the previous two weeks. Urine output was reduced. Stools were of normal consistency and frequency. His parents were healthy and unrelated; his 6-year-old sister was also healthy. He was born from normal pregnancy and delivery, his birth weight was $4.1 \mathrm{~kg}$, and he had normal postnatal course and regular weight gain. He was not breastfed; since birth he was fed an adapted formula based on cow's milk. At the age of 6 months, cereals were introduced in his diet but without any reaction. However, since his second year of life, his mother noticed different skin reactions with rashes to various food products and generalized urticaria provoked by peanuts. Skin prick tests undertaken for nutritive allergens excluded milk protein allergy, but were positive for peanuts, which were thus excluded from his diet. At the age of 2.5 years, taking peanuts by mistake resulted in development of Quincke's edema that was treated with steroids by his pedi-

* Clinical Hospital Centre Rijeka, Krešimirova 42, 51000 Rijeka

\section{Correspondence to:}

Ivona Butorac Ahel, dr. med., Clinical Hospital Centre Rijeka, Krešimirova 42, 51000 Rijeka, e-mail: ivonabuah@gmail.com

Primljeno/Received: 15. 2. 2015., Prihvaćeno/Accepted: 10. 4. 2015. 
TABLE 1. Etiology and pathopysiology of edema in children

Generalized edema
Increased capillary hydrostatic pressure
Heart failure
$\quad$ Primary renal disease
Nephrotic syndrome
Acute glomerulonephritis
Renal failure
Liver cirrhosis
Decreased capillary oncotic pressure
Nephrotic syndrome
Liver failure
Protein losing enteropathy
Protein malnutrition
Increased capillary permeability
Sepsis
Burns

atrician. Since then, he was treated with steroids several times because of obstructive bronchitis, with the last treatment only a week before current admission.

At admission, the examination showed significant edema of the eyelids and pitting edema of both hands, legs and perigenital region. The abdomen was not distended. He was afebrile with normal vital signs. His weight was on the $75^{\text {th }}$ and his height on the $95^{\text {th }}$ percentile for his age. He was on the $95^{\text {th }}$ weight for height percentile. Laboratory findings including blood count, renal parameters, liver tests and coagulation tests were within the normal ranges, except for hypoproteinemia, hypoalbuminemia, hypoglobulinemia and hypercholesterolemia. Plasma concentrations of urea and creatinine were normal. Urinalysis showed mild proteinuria with normal microscopy of urine sediment. Spot urine was analyzed several times confirming mild proteinuria (the urinary protein/creatinine ratio was 0.02-0.03 g/ $\mathrm{mmol}$ ). The results of laboratory investigations are shown in Table 2. The initial treatment consisted of intravenous administration of albumin, diuretics and fluid restriction. Ultrasound of the abdomen and echocardiography were unremarkable, without ascites or cardiac effusion. Pleural ultrasound showed minimal pleural effusion of $1 \mathrm{~mm}$. Based on previous medical history, earlier treatment with steroids, the findings of generalized edema with mild proteinuria, hypoalbuminemia and hypercholesterolemia, renal biopsy was performed for suspicion of nephrotic syndrome, which is the most common cause of generalized edema in preschool children. Renal biopsy, including light microscopy and immunofluorescence, was normal without podocyte reaction and without complement and immune deposits. Excluding cardiac and renal pathology as the most common cause of generalized pitting edema, additional workup
TABLE 2. Results of laboratory investigations performed at diagnosis

\begin{tabular}{|c|c|c|}
\hline Serum & At diagnosis & Reference values \\
\hline Erythrocite (x10²/I) & 5.45 & $4.0-5.0$ \\
\hline Hemoglobin (g/l) & 117 & $109-138$ \\
\hline Leukocytes (x109/I) & 12.1 & $5.0-13.0$ \\
\hline Platelets (x109/I) & 850 & $150-450$ \\
\hline Urea (mmol/l) & 2.7 & $1.8-6.0$ \\
\hline Creatinine $(\mu \mathrm{mol} / \mathrm{l})$ & 43 & $35-62$ \\
\hline Sodium (mmol/l) & 139 & $134-143$ \\
\hline Potassium (mmol/l) & 4.5 & $3.5-6.0$ \\
\hline Albumin (g/l) & 20.1 & $28-48$ \\
\hline Total protein (g/l) & 35 & $55-80$ \\
\hline AST (U/I) & 28 & $24-49$ \\
\hline $\mathrm{ALT}(\mathrm{U} / \mathrm{I})$ & 13 & $9-20$ \\
\hline GGT (U/I) & 5 & $4-22$ \\
\hline Cholesterol (mmol/l) & 4.8 & $<4.7$ \\
\hline Triglycerides (mmol/l) & 2.5 & $0.3-1.1$ \\
\hline C3 (g/l) & 1.29 & $0.9-1.8$ \\
\hline C4 (g/l) & 0.31 & $0.1-0.4$ \\
\hline $\lg G(g / l)$ & 1.8 & 4-16 \\
\hline $\lg M(g / l)$ & 0.4 & $0.5-2$ \\
\hline $\lg A(g / \operatorname{l})$ & 0.5 & $0.2-1.3$ \\
\hline $\begin{array}{l}\text { Coagulation tests: } \\
\text { PT } \\
\text { INR }\end{array}$ & $\begin{array}{l}0.95 \\
2.1\end{array}$ & $\begin{array}{l}0.7-1.3 \\
2.0-3.5\end{array}$ \\
\hline
\end{tabular}

AST $=$ aspartate aminotransferase, $\mathrm{ALT}=$ alanine aminotransferase, $\mathrm{GGT}=\gamma$-glutamyl-transpeptidase, $\mathrm{PT}=$ prothrombin time, INR = International Normalised Ratio

was performed. Other potential causes of hypoalbuminemia and edema, such as cystic fibrosis, hereditary angioedema and celiac disease were taken into consideration. Sweat test was negative; C3 and C4 levels and C1 inhibitor leve were normal. The measurement of stool alpha-1-antitrypsin was not available in our hospital. Test for tissue transglutaminase lgA antibodies was $156 \mathrm{RU} / \mathrm{mL}$ (normal range <20 RU/ $\mathrm{mL}$ ), indicating the need of small intestine biopsy. Ultimately, the small intestine biopsy confirmed the diagnosis of CD. According to Marsh's classification, histologic features were typical for stage 3B: villous atrophy, crypt hypertrophy and intraepithelial lymphocytes (6) (Figure 1). The results of testing for human leukocyte antigen (HLA) DQ2 were positive and for DQ8 negative. The patient was diagnosed to have CD and a gluten-free diet was recommended. After starting the gluten-free diet, edema started to disappear gradually, followed by normalization of serum albumin concentration. Since the diagnosis of $C D$, the boy has been regularly followed up every six months. With a gluten-free diet, he has no symptoms characteristic of CD and the value of tissue transglutaminase IgA antibodies normalized after six months. Before hospital discharge and one month after 


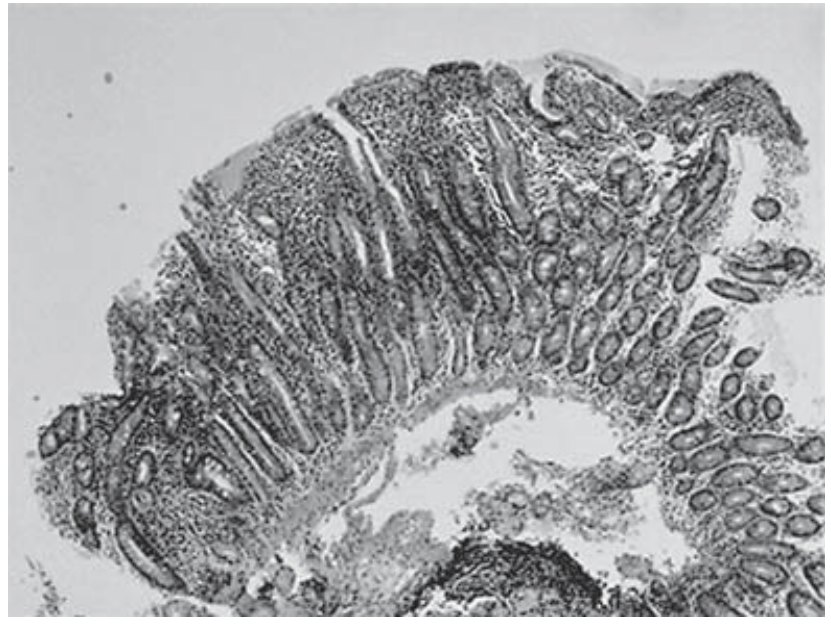

FIGURE 1. Biopsy of duodenum: complete villous atrophy associated with hyperplasia of glandular crypts; increased number of intraepithelial lymphocytes. (HE, X10)

urine spot was analyzed, proteinuria was not recorded. Screening of the family for $C D$ revealed the diagnosis of $C D$ in his mother and older sister, confirmed by positive specific autoantibodies and biopsy of the small intestine in his sister.

\section{DISCUSSION}

Differential diagnosis of generalized edema is quite broad and diagnostic approach is based on the pathogenesis of edema. Based on laboratory findings of hypoalbuminemia, it was assumed that generalized edema was the result of hypoalbuminemia and decreased capillary oncotic pressure. The possible causes of hypoalbuminemia in childhood are nephrotic syndrome, liver failure, protein losing enteropathy, and protein malnutrition. Nephrotic syndrome is one of the most common causes of generalized edema in childhood. Besides generalized edema, the syndrome is characterized by marked proteinuria, hypoalbuminemia and hyperlipidemia. Although the patient did not show marked proteinuria, his medical history (taking steroids) and marked hypoalbuminemia with generalized pitting edema were suggestive of renal etiology. The results of renal biopsy including light and immunofluorescence studies were unremarkable and excluded renal pathology. Based on the normal hepatic function test and coagulation tests, liver disease was excluded as well. Initially, as the patient's body mass and height were within the normal range for his age, protein malnutrition was not considered as a possible cause of generalized edema. Protein losing enteropathy is a diverse group of disorders associated with excessive loss of serum protein through the gastrointestinal tract. The most affected protein is albumin, although other proteins such as immunoglobulin and ceruloplasmin are also affected. It is important to emphasize that before considering protein losing enteropathy as a potential cause of hypoproteinemia, other causes of hypoproteinemia mentioned above had to be excluded. There are two mechanisms behind the increased protein loss through the intestinal tract, i.e. mucosal injury and abnormalities of the lymphatic system. Lymphatic abnormalities responsible for protein losing enteropathy are primary and secondary intestinal lymphangiectasia. Numerous conditions can induce injury of intestinal mucosa and protein loss, such as inflammatory bowel disease, infections, gastrointestinal malignancy, milk protein allergy, celiac disease and Menetrier's disease. A test for tissue transglutaminase IgA antibodies was performed and the findings were suggestive of CD. Intestinal biopsy confirmed the diagnosis of CD. Protein loss in CD is a result of the loss of villi and surface epithelium, which ease the leakage of plasma proteins (7).

Celiac disease is considered to be the most common genetically predetermined condition with a prevalence of $1 \%$ in many European countries (4-8). The understanding of this disease has changed from gastrointestinal disease to a multisystem immune disorder (9).

Clinical presentation of CD varies, including cases of either typical gastrointestinal features manifesting during the first two years of life or atypical extraintestinal features manifesting later in life. Typical symptoms of CD are diarrhea, abdominal distention, weight loss, failure to thrive, anorexia and irritability. Atypical presentation includes extraintestinal symptoms such as isolated anemia, short stature, delayed puberty, hepatitis, arthritis, ataxia, headache, depression, dermatitis herpetiformis and altered bone metabolism (9). Also, patients may present some gastrointestinal symptoms that were considered highly unusual for CD, such as constipation, vomiting and recurrent abdominal pain. Several recent studies have shown that typical symptoms of $C D$ are absent in half of the newly diagnosed cases (9-12). One in four patients with $C D$ does not report any gastrointestinal symptomatology, as in our case.

Nowadays, attention is focused on the symptoms that were until recently considered unusual for the diagnosis of $C D$ (13). Whilst some features of CD have become more acceptable and recognizable as part of CD presentation, generalized edema caused by severe hypoalbuminemia in $C D$ is rare. Kuloglu et al. report on the $9.5 \%$ prevalence of hypoalbuminemia and $3.5 \%$ of peripheral edema in CD patients (14). In another report, CD presented with generalized edema in two patients with coexisting CD and intestinal lymphangiectasia (15).

In our patient, CD coincided with urticaria. Urticaria is an immunoglobulin (Ig)-E-mediated allergic reaction, while CD is an immune-mediated enteropathy caused by aberrant response to gluten in genetically susceptible individuals. 
Besides CD, gluten can cause wheat allergy and gluten sensitivity.

Because of the fact that the first-degree relatives of celiac patients are at a higher risk of CD, the patient's parents and his older sister underwent screening too. Although completely asymptomatic, his mother and older sister had silent CD confirmed by positive specific autoantibodies and biopsy of the small intestine.

In conclusion, clinical presentation of CD is very heterogeneous and the diagnosis of CD should be considered even in the presence of atypical symptoms.

\section{NOVČANA POTPORA/FUNDING}

Nema/None

\section{ETIČKO ODOBRENJE/ETHICAL APPROVAL}

Nije potrebno/None

\section{SUKOB INTERESA/CONFLICT OF INTEREST}

Autori su popunili the Unified Competing Interest form na www.icmje.org/ coi_disclosure.pdf (dostupno na zahtjev) obrazac i izjavljuju: nemaju potporu niti jedne organizacije za objavljeni rad; nemaju financijsku potporu niti jedne organizacije koja bi mogla imati interes za objavu ovog rada u posljednje 3 godine; nemaju drugih veza ili aktivnosti koje bi mogle utjecati na objavljeni rad./All authors have completed the Unified Competing Interest form at www.icmje.org/coi_disclosure.pdf (available on request from the corresponding author) and declare: no support from any organization for the submitted work; no financial relationships with any organizations that might have an interest in the submitted work in the previous 3 years; no other relationships or activities that could appear to have influenced the submitted work.

\section{REFERENCES}

1. Kimura G. Pathogenesis of edema and its classification. Nihon Rinsho. 2005;63:11-6.
2. Catassi $C$, Anderson RP, Hill ID, et al. World perspective on celiac disease. J Pediatr Gastroenterol Nutr. 2012;55:494-9. doi: 10.1097/MPG.0b013e318272adf4.

3. Husby S, Koletzko S, Korponay-Szabó IR, et al. European Society for Pediatric Gastroenterology, Hepatology, and Nutrition Guidelines for the Diagnosis of Coeliac Disease. J Pediatr Gastroenterol Nutr. 2012;54:136-60.

4. Mišak Z, Hojsak I, Jadrešin O, Kekez AJ, Abdović S, Kolaček S. Diagnosis of coeliac disease in children younger than 2 years. J Pediatr Gastroenterol Nutr. 2013;56:201-5. doi: 10.1097/MPG.0b013e3182716861.

5. Alaedini A, Green PH. Narrative review: celiac disease: understanding a complex autoimmune disorder. Ann Intern Med. 2005;142:289-98.

6. Oberhuber G, Granditsch G, Vogelsang H. The histopathology of coeliac disease: time for a standardized report scheme for pathologists. Eur J Gastroenterol Hepatol. 1999;11:1185-94.

7. Braamskamp MJ, Dolman KM, Tabbers MM. Clinical practice. Protein losing enteropathy in children. Eur J Pediatr. 2010;169:1179-85. doi: 10.1007/s00431-010-1235-2.

8. Rewers M. Epidemilogy of celiac disease: What are the prevalence, incidence and progression of celiac disease? Gastroenterology. 2005;128:S47-S51.

9. Roma $\mathrm{E}$, Panayiotou J, Karantana $\mathrm{H}$, et al. Changing pattern in the clinical presentation of pediatric celiac disease: a 30-year study. Digestion. 2009;80:180-91. doi: 10.1159/000227275.

10. Steens RF, Csizmadia CG, George EK, Ninaber MK, Hira Sing RA, Mearin ML. A national prospective study on childhood celiac disease in the Netherlands 1993-2000: an increasing recognition and a changing clinical picture. J Pediatr. 2005;147:239-43.

11. Ravikumara $M$, Tuthill DP, Jenkins HR. The changing clinical presentation of coeliac disease. Arch Dis Child. 2006;91:969-71.

12. Garampazzi A, Rapa A, Mura S, Capelli A, Valori A, Boldorini R, Oderda G. Clinical pattern of celiac disease is still changing. J Pediatr Gastroenterol Nutr. 2007;45:611-4.

13. Green PH, Jabri B. Coeliac disease. Lancet. 2003;362:383-91.

14. Kuloğlu Z, Kirsaçlioğlu CT, Kansu A, Ensari A, Girgin N. Celiac disease: presentation of 109 children. Yonsei Med J. 2009;50:617-23. doi: 10.3349/ymj.2009.50.5.617.

15. Perisic N, Kokai G. Coeliac disease and lymphangiectasia. Arch Dis Child. 1992;67:134-6.

\title{
Generalizirani edem s hipoproteinemijom kao prva prezentacija celijakije u 3-godišnjeg dječaka
}

\author{
I. Butorac Ahel, M. Šubat Dežulović, G. Palčevski
}

Edemi nastaju zbog abnormalnog nakupljanja tekućine u intersticiju. Diferencijalna dijagnoza edema je vrlo široka. Bubrežni i srčani uzroci su najčešći uzroci generaliziranih edema. Mogući gastrointestinalni uzroci edema su zatajenje jetre, enteropatija uzrokovana gubitkom proteina, uključujući celijakiju i proteinsku neishranjenost. Generalizirani edemi su rijetka prva manifestacija celijakije. Prikazujemo slučaj trogodišnjeg dječaka s celijakijom koji se inicijalno prezentirao generaliziranim edemima i hipoproteinemijom. 